\title{
MUCOCELE LABIAL, ASPECTOS CLÍNICOS E TRATAMENTO
}

Janaina Mara DISSENHA, Cleverson Luciano TRENTO

Mucocele é uma lesão benigna comum da mucosa oral, assintomática e causada pelo rompimento do ducto de glândulas salivares menores. A localização mais comum para se encontrar uma mucocele é a superfície do lábio inferior, sendo o seu desenvolvimento na maioria das vezes de origem traumática. O objetivo deste trabalho é mostrar clinicamente uma lesão de mucocele e seu tratamento. Paciente do sexo masculino, 22 anos, compareceu a clínica de odontologia do Cesumar com uma tumefação visível, assintomática, de coloração esbranquiçada, localizada no lábio inferior do lado direito. O tratamento da lesão consistiu em uma excisão cirúrgica com remoção das glândulas salivares envolvidas. Ao exame histopatológico verificou-se estroma conjuntivo apresentando células adiposas (próprias da área) e presença de área com infiltrado inflamatório com áreas de agudização (eosinófilos); que foi motivo de questionamento se houve ou havia uso de qualquer objeto traumatizando a área. A reparação tecidual após a cirurgia foi satisfatória, sem recidiva da lesão em seis meses de proservação, apresentando prognóstico favorável, devendo-se ainda orientar o paciente quanto a traumatismos locais no sentido de se evitar o aparecimento de novas lesões.

Palavras-chave: Mucocele; lábio; glândulas salivares 